\title{
JANA DUFFKOVÁ
}

\section{HOMEWORK, TELEWORK A SPOL. NEBOLI PŘÍLIŠ MNOHO „WORKU゚“‘}

Situace, kdy drtivá většina pracujících pracuje ve víceméně shodném, přesně vymezeném čase „od - do“ v prostorách podniku, instituce, firmy či továrny, je minulostí. Je to minulost ne $\mathrm{v}$ absolutním smyslu, tj. nikoli neexistence takových profesí a zaměstnání a takových pracovníků, ale v relativním významu: podíl těchto pracovních podmínek a osob pracujî́cích $\mathrm{v}$ jejich rámci se zmenšuje (byt je stále převládající - u nás dokonce velice výrazně převládající). Různé proměny probíhají samožrejmě v rámci tradičních pracovních podmínek a tradičních pracovních vztahů, kde roste variantnost, flexibilnost a samostatnost zaměstnanců, ale nejžretelnějši změnou je vznik a rozšriření nestandardních typů a forem výkonu pracovní činnosti. Jedním z těchto nových trendů je telework(ing), volně navazující na homework(ing), známý již z minulosti.

\section{HOMEWORK(ING) NEBOLI „PRÁCE DOMA“}

Homework $\mathrm{v}$ angličtině, z níž je tento termín do češtiny přejat, znamená:

1. „ک̌kolní práce, která má být udělána mimo třídu“ (odlišuje se od práce ve třídě, tj. práce, kterou žák dělá ve tř́íě),

2. „důkladné př́pravné studium subjektu“ (např. pro schůzi komise apod.),

3. ,práce vykonávaná doma jako práce úkolová“.”

1 Omlouvám se za osobní poznámku, a to ještě v titulku. Jakkoli osobně nepřiliš dobře snáším samoúčelné, násilné zavádění mnohdy neobratných až komických neologismů či lingvistických -ismů zahraničního pủvodu ( $v$ našich podmínkách zejména anglicismủ či germanismú, dřive rusismủ), $v$ daném př́padě mi nezbylo než kapitulovat před neuchopitelností termínů ,homework“" a "telework“. Ceské výrazy, které se $\mathrm{v}$ těchto souvislostech doposud objevily, považuji př̀nejmenším za nepřesné, velice často za dvojznačné a matoucí, prímo vybizejićí $\mathrm{k}$ záměně a nedorozumění (bliže a konkrétně viz pasáže o terminologických problémech u každé $\mathrm{z}$ kategorii); vytvářet novotvary ve stylu obrozeneckých kapsonososmrkoplen mi připadá ještě horší a soustavný slovní opis termínủ kličových pro tuto stat́ by zdvojnásobil její rozsah a vedl po cestě jazykového purismu (i puritanismu) do pekel obsahové nesrozumitelnosti a chaosu. Ve snaze o stručné a zároveň jednoznačné pojmenováni tedy v následujícím textu budou použivány $\mathrm{z}$ angličtiny přejaté výrazy homework a telework a s nimi souvisejici homeworker a teleworker $\mathrm{v}$ pưvodním znění a - což je jádro problému a kámen pochybností - budou také př́slušně skloňovány i jinak ohýbány (i když výraz ,,workư $\mathrm{z}$ podtitulu stati je ojedinělý a myšlený spiše $v$ určité nadsázce).

2 AZ Dictionary; dostupné na www.infoplease.com. 
Homeworker jako vykonavatel, nositel je pak:

1. „domácí paní, hospodyně“,

2. „osoba, která pracuje doma za plat/mzdu, hlavně osoba vykonávající úkolovou práci“.3.

U nás se dnes slovo homework (event. homeworking) objevuje prakticky výlučně ve významech souvisejících s placenou prací vykonávanou v prostředí domova; používá se - a to stále častěji - zhruba od začátku 90. let minulého století. Tato „novost“ je ovšem jen velice relativní: souvisí spíše s formálním pojmenováním než s obsahovou podstatou: pod českým označením „domácí práce“ má u nás daná forma zaměstnávání podstatně delší tradici.

Právě u českého synonyma, přesněji řečeno u překladu slova homework nastávají určité jazykové nesrovnalosti a možnosti nedorozumění. Čeština sice nemá problém jako je tomu v angličtině - možné slovní záměny placené práce doma s domácím úkolem žáka ${ }^{4}$ (obojí je homework, jak je zmíněno výše), ale objevuje se zde jiná dvojznačnost. „Domácí práce“ (doslovný překlad výrazu homework) totiž může zcela běžně znamenat jak (a) realizaci zaměstnání, výkon profese $\mathrm{v}$ prostředí domova pracovníka, tak i (b) běžné činnosti sloužící k zajištění provozu domácnosti a chodu rodiny, tj. úklid, nákup, přípravu jídla, údržbu domácích spotřebičů, šití apod. (v angličtině je analogická dvojznačnost částečně patrná až u slova homeworker ve významu ,hospodyně“). Obsahové rozdíly jsou sice jasné („doma“ a „domácí“ v prvním významu zdůrazňuje méně obvyklé místo vykonávání profesní pracovni aktivity, jeji lokalizaci, a v druhém představuje spíše charakteristiku typu a náplně činnosti), ale odlišení $\mathrm{z}$ pouhého termínu není možné. Ještě neštastnější a méně přihodné (naštěstí $\mathrm{i}$ ojedinělé) je použivání českého výrazu ,práce v domácnosti“ místo homework - zde je v češtině ještě výraznější asociace s ,péčí o domácnost“, tedy opět se zmíněným úklidem, nákupem apod. Vzhledem $\mathrm{k}$ tomu, že navíc jde o jevy, které se mohou velice snadno "setkat" při analýze jednoho problémového okruhu (patři do stejné tematické oblasti), bylo by vhodné jejich apriorní odlišení zřetelné na první pohled, a to např. $\mathrm{v}$ této podobě: běžné činnosti sloužící $\mathrm{k}$ zajišsění provozu domácnosti a existence rodiny = domácí práce; realizace zaměstnání, výkon profese v prostředí domova = homework (pro českou variantu by bylo možné použivat nejspíše termín ,práce doma“, případně přesněji, ale poněkud krkolomně ,práce v domově“).

O něco jednodušší je situace při pojmenování nositele práce doma: anglickému výrazu homeworker odpovídá $\mathrm{v}$ různých materiálech zabývajících se $\mathrm{v}$ současnosti u nás danou problematikou nejčastěji český termín „domácí pracovník/zaměstnanec“ či „domácký pracovník/zaměstnanec“ (výjimkou ale rozhodně není ani používání původního anglického výrazu). $\mathrm{V}$ tomto případě však český kontext obsahuje jinou významovou záludnost: zde se naplno projevuje pejorativni podtext či nádech v sou-

3 Tamtéž.

4 Mimochodem, je zajímavé, že po zadáni klíčového slova homework do jakéhokoli internetového vyhledavače $v$ angličtině se následně objeví nejprve záplava odkazů na internetové stránky, které mají pomoci žákủm a studentủm napsat (event. přimo opsat) písemné práce na rủzná témata, tedy domácí úkoly, a teprve poté se najdou i odkazy na homework ve významu použivaném v této stati.

5 Jazykově-logickou hádankou pak mủže být následujicí otázka: Rekneme-li, že dopoledne homeworker vykonává domácí práci, rozumí se tím to, že dopoledne uklízi a vaří, nebo naopak že dopoledne se věnuje placeným činnostem své profese? 
vislosti s „domácí prací“, event. snad ještě výrazněji se synonymním pojmem „práce po domácku“ 6 (tento termín navíc vyvolává představu práce nepř́liš kvalitně provedené, jaksi provizorní, neprofesionální, $\mathrm{s}$ jasným rizikem nedokonalosti apod.). Výsledkem je, že identifikací (či sebeidentifikací) „domácí (domácký) zaměstnanec“ spíše poklesne prestiž dotyčného pracovníka, at doma realizuje jakkoli významnou profesi a je v ní jakkoli úspěšný a uznávaný. Obecné povědomí zde totiž př́liš často „domácího pracovníka" asociuje - kromě výše uvedeného - s představou tradičního homeworku, který byl a dodnes částečně je spojován spíše s pojetím zaměstnání jakožto pouhého zdroje finančních prostředků (a to ještě nepřiliš velkých) než s pojetím profese jakožto základu seberealizace i sociálního (socioekonomického) statusu. ${ }^{7}$

\section{TRADIČNI HOMEWORK}

Jak jsme již zmínili, homework (pod poněkud zavádějícím označením „domácí práce“) v Čechách v praxi existoval dlouho před 90 . lety minulého století. Jednalo se o to, čemu se občas říká „klasický homework“ či „tradiční homework“ ${ }^{8}$ - v našich podmínkách patři ke starším všeobecně známým prototypům homeworku především domácí výroba tkalců $v$ Podkrkonoší, kteří svoje dílo odevzdávali v osmnáctém a devatenáctém století faktorům, nebo ruční navlékání korálkủ. Dodnes se za typické činnosti pro tradiční homework považuje především ( $v$ dojemné shodě našich i zahraničních autorů) pletení či nadepisování a zalepování poštovních obálek.

Obvykle bývají zdưrazňovány horší pracovní podmínky domácích pracovníkủ ve srovnání s pracovníky každodenně dojíždějícími do zaměstnání - konkrétně jde o:

- nízké platy (s prodloužením nízké částky do výpočtu výše důchodu, pokud něco takového vůbec přichází v úvahu),

- nejistotu v trvalosti zaměstnání (ústící až v určitou existenční závislost na zaměstnavateli či zadavateli pracovních úkolů),

- velice často i o nevýhodnou nebo problematickou (či dokonce žádnou) pracovní smlouvu,

- neexistenci dodatkových dílčích pracovních výhod (typu př́platků na stravování apod.),

- další momenty související s neposkytnutím (nemožnosti poskytnutí, zbytečnosti poskytnutí) stejných podmínek homeworkerovi jako zaměstnanci pracujícímu $\mathrm{v}$ prostorech zaměstnavatele, a to i u stejné činnosti.

Poslední obecnou poznámku lze konkretizovat a dokumentovat na pracovní legislativě týkající se domácích pracovníků v ČR. V našich současných podmínkách ${ }^{9}$ jsou domácí pracovníci charakterizováni jako zaměstnanci, kteři „nepracují na pracovištích zaměstnavatele, ale podle podmínek dohodnutých $v$ pracovní smlouvě pro něj vykonávají sjednané práce doma v pracovní době, kterou si sami rozvrhuji (... “ “. ${ }^{10}$ Pracovní

6 Použito např. v článku Trh práce v pohybu. Práce na dálku. Ekonom, č. 48, 1991.

7 I tato negativní asociace je dủvodem, proč daný text preferuje anglickou (či spíše poangličtělou) verzi názvosloví, a tedy kromě homework i homeworker.

8 Toto označení se objevuje např. v dokumentech Mezinárodni organizace práce (ILO).

9 Viz např. stávající Zákoník práce - ustanovení \$ 267 odst. 2 a 3.

10 Citováno podle: MATEJKA, J.: Distanční výkon práce a jeho právní úprava; dostupné na www.lupa.cz. 
poměry homeworkerů se říí ustanoveními Zákoníku práce s následujícími odchylkami, které vlastně homeworkerủm brání využivat některé ohledy a výhody, jež pro nehomeworkery běžně platí: na homeworkery se např. nevztahuje ustanovení o rozvržení stanovené pracovní doby a o prostojích, při dủležitých osobních překážkách v práci jim nenáleži od zaměstnavatele náhrada mzdy, nenáleží jim př́platek za práci přesčas ani př́íplatek za práci ve svátek, v noci, o víkendu, popř́padě ani další složky mzdy stanovené mzdovým předpisem. ${ }^{11}$ Tyto odchylky jsou pochopitelně na úrovni teorie a zásadních principů logické vzhledem $\mathrm{k}$ tomu, že situaci, $\mathrm{v}$ níž by pracovník $\mathrm{u}$ zaměstnavatele musel pracovat mimo „standardní dobu“, může homeworker předcházet právě díky tomu, že si sám může volit čas, kdy bude svou práci pro zaměstnavatele vykonávat ( $v$ praxi však může zaměstnavatel homeworkera $\mathrm{k}$ neplacené noční či víkendové práci nepřímo donutit stanovením krátkého termínu odevzdání dílčího úkolu).

Horší pracovní podmínky homeworkeři přijímají, protože - a to jejich zaměstnavatelé velmi dobře vědí - zpravidla nemají př́liš na výběr: na homework tohoto typu přistupují lidé, kteří by velice obtížně získali lepší zaměstnání, a to bư kvưli nepříznivým podmínkám a vyhlídkám zaměstnanosti v určité lokalitě, nebo vzhledem ke své osobní specifické situaci (do níž lze zařadit i př́ípady nelegálního zaměstnávání, „práce načerno" osob, které by z dủvodủ právních zábran nemohly být zaměstnány legálně). Snad nejčastějjší „subjektivni“" okolností silně redukující šanci na lépe placené i kariérově slibnější zaměstnání je vázanost těchto osob na místo bydliště, event. přímo na prostředí bytu, domova: hlavními důvody v pozadí je zpravidla dlouhodobé či trvalé vlastní onemocnění nebo postižení a pravidelná dlouhodobá péče o někoho nemocného či postiženého nebo o malé dítě. $K$ dalším př́činám spokojení se $s$ tradičním homeworkem se řadí nedostatečná (či žádná) kvalifikace homeworkera - v drtivé většině případů jsou činnosti, které se nabízejí coby homework, jednodušší, rutinní až mechanické, nenáročné, vyžadující opravdu jen základní znalosti či dovednosti, event. dovednosti, které lze získat krátkodobou praxí. ${ }^{12}$ Mezi dodnes nejčastěji realizované pracovní činnosti formou homeworku patř́ šití (v rámci nejen textilního, oděvního, ale i kožařského průmyslu), sestavování hraček nebo dalších jednoduchých předmětư, výroba rủzných suvenýrů, $\mathrm{z}$ „modernizovanějších“ aktivit lze jmenovat kompletaci propagačních či jiných písemných materiálů, přepisování záznamů z audiokazet na psacím stroji (tzv. audio-stenotypistky) apod. ${ }^{13}$ Za důležitý charakteristický znak homeworku se považuje také jednoduchost, nenáročnost a obecnější dostupnost nutně

11 Blî̌ze viz tamtéž.

12 Zcela zvláštním a ve své podstatě jiným případem jsou činnosti vykonávané sice často v domácím prostředí, ale vyžadujíci specifickou zručnost i zkušenost pracovnika, např. složité a náročné ruční vyšivání, ruční tkaní kobercủ, ruční malování na sklo apod.. Kvalitně provedená ruční práce (hand made) v tomto smyslu patři spíše do kolonky „umělecká ručni práce“ či ,užité uměni“" a má charakter ,originálního zboži“ nebo dokonce ,luxusního zboži“ (zboži na přaní, podle individuální objednávky) - blíží se tedy mnohem více uměleckým profesím v rámci tzv. svobodných povolání, ačkoli spiše než o ,umění ju je o ,umělecké remeslo“.

13 Nutno konstatovat, že v souvislosti se současným homeworkem se casto upozorñuje na možná nebezpečí rủzných podvodủ či přinejmenším nepř́liš ,čistých“ praktik. Př́kladem může být homework v rámci tzv. MLM-systému (multilevel marketing), kdy výdělek zaměstnance závisí ne na tom, kolik určitého zboži dokáže člověk prodat, ale na tom, kolik lidí se mu podaři přesvědčit ke stejné práci, tj. $\mathrm{k}$ tomu, aby se také stali prodejci téhož systému (princip je stejný jako u tzv. pyramidových her typu letadlo - jak tvrdí experti na tuto problematiku, stejný je také výsledek). Negativně je rovněž hodnocen v našich ,pracovních" inzerátech dosti frekventovaný typ zajištování homeworku, kdy je homeworker např. př̀ kompletaci rüzých hraček nucen nejprve si díly, z nichž hračky skládá, od zadavatele koupit. 
používaných nástrojů a pomůcek (šicí stroj + nitě, psací stroj + papír atd.). Vzhledem $\mathrm{k}$ výše uvedeným základním momentům jistě nemůže překvapit skutečnost, že drtivou většinu homeworkerů $v$ tradičním významu ve světě tvoři ženy.

\section{3. „SVOBODNÁ POVOLÁNÍ“ MEZI HOMEWORKERY?}

Nelze si nevšimnout, že kromě typů výše uváděných př́kladů existuje ještě zcela specifická skupina osob, jejichž profesní činnost snad nikoho nenapadne spojovat s pravidelnou pracovní dobou ,od - do“ v úřadu, firmě, kanceláři, obecně v prostoru, v němž by obdobnou činnost vykonávalo více pracovníkủ a u nichž se naopak alespoň částečná práce doma jaksi samozřejmě předpokládá, aniž by se tato skutečnost zvláště zdủrazňovala: jde o tzv. svobodná povolání, kam se řadí především umělci různého zaměření (nejtypičtějši jsou v tomto ohledu patrně spisovatelé), advokáti, novináři, překladatelé a další.

Tato povolání mají přes veškerou vnitřní obsahovou různost určité společné charakteristické rysy, jimiž jsou hlavně vysoká a specializovaná kvalifikace (včetně nutné míry talentu u většiny těchto profesí), kreativní podstata s vysokou mírou samostatného rozhodování, přinejmenším částečná či dočasná individuálnost práce. Zároveň lze zaznamenat významné rozdíly celé této skupiny osob oproti homeworkerům v klasickém (výše uvedeném) slova smyslu, $\mathrm{z}$ nichž nejdůležitější jsou patrně tyto:

- přislušníci svobodných povolání pracují významnou měrou doma, ale nemusí to nutně být jejich jediný pracovní prostor (spisovatel nebo překladatel sice může psát či prekládat pouze doma, ale žurnalista dochází do redakce a za reportážemi do terénu, advokát se schází s klienty a dochází na zasedání soudu atd.);

- mezi přislušníky svobodných povolání je méně zaměstnanců (zejména zaměstnancủ jednoho zaměstnavatele) a více samostatně pracujících, než je tomu u tradičního homeworku (svobodná povolání jsou koneckonců „svobodná“, a to jak pokud jde o prostor a dobu výkonu profese, tak často i pokud jde o trvalého zaměstnavatele);

- finanční př́ijmy i prestiž jsou u svobodných povolání nesrovnatelně vyšší.

Na jedné straně považujeme-li u homeworku za zásadní znak lokalizaci pracovní činnosti (domov), nemůžeme skupinu přislušníkủ svobodných povolání z této kategorie vynechat, na druhé straně je ovšem jasné, že některé jejich další charakteristické rysy se se znaky běžného homeworkera zásadně neshodují. Kličem $k$ řešení této nejednoznačnosti může být důležitý doplněk $\mathrm{k}$ vymezení lokalizace homeworku: při charakteristice homeworku se sice zdůrazňuje výslovně především to, že jde o pracovní profesní činnost vykonávanou doma, ale v pozadí se skrývá i (ne vždy výslovně artikulovaná) představa, že homework je práce vykonávaná na jiném než obvyklém místě, tedy jinde než na běžném pracovišti, v prostorech zaměstnavatele apod. $.^{14}-\mathrm{u}$ mno-

14 Nutná existence tohoto „obvyklého, běžného pracoviště“ (jiného než je domov) poukazuje na počátky homeworku - o homeworku má smysl mluvit teprve od té doby, kdy se ekonomická funkce rodiny začíná modifikovat, a hlavně přenášet mimo domov, kdy je pro většinu obyvatel obvyklejší pracovat jako jednotlivci (tj. bez zapojení dalších rodinných pứslušníkủ) mimo domov než doma spolu alespon̆ s částí rodiny. V našich současných podminkách je určitou renesancí ekonomické funkce rodiny spiše provozování rưzných ,rodinných podnikù “ (rodinné farmy, hotely atd.) než sama skutečnost, že jeden člen rodiny pracuje doma, at již jako homeworker nebo teleworker. 
ha svobodných povolání je však (jak je naznačeno v úvodním odstavci této kapitolky) obvyklým místem výkonu práce právě domov a řada jejich představitelů by ani jinde než v prostředí domova nemohla pracovat, nelze tedy identifikovat jejich jiný „obvyklý pracovní prostor" ${ }^{15}$ Řadit př́slušníky svobodných povolání mezi homeworkery (z hlediska práce) je tedy víc než sporné, ale zároveň je pravda, že mnoho sociálních a sociálně-psychologických souvislostí a okolností situace výkonu profese v domácím prostředí (např. v komunikaci, rodinném životě apod.) je shodných či přinejmenším obdobných jak u homeworkerů, tak u př́slušníků svobodných povolání. ${ }^{16}$

\section{OUTWORK(ING) NEBOLI „PRÁCE MIMO“}

U většiny autorů zabývajících se problematikou homeworku je za jeho základní vymezující rys a zpravidla i výslovné kritérium považována skutečnost, že jde o práci vykonávanou v domácím prostředí pracovníka, tedy primárně specifická je především konkrétní lokalizace pracovní činnosti - tj. domov. Přesto existují i autoři, kteří kladou ve svých pojetích větši důraz na to, kde u homeworku pracovní činnost vykonávaná není, než na to, kde je: podstatnější je zde stanovení, že homework vykonávají pracovníci mimo pracoviště zaměstnavatele, než otázka, kde tak konkrétně činí, jestli ve svém místě bydliště, tedy doma, nebo někde jinde (většinou se uvádí různé stylistické variace na téma „homeworker pracuje mimo pracoviště zaměstnavatele doma nebo podle svého výběru jinde“"17).

Je třeba říci, že toto široké pojetí homeworku je nejsilněji zastoupeno v řadě stávajících mezinárodních oficiálních dokumentů, $\mathrm{v}$ materiálech institucí a organizací vytvářejících legislativní základnu homeworku (konkrétně viz definici homeworkera v následující kapitole o diskusích v rámci Mezinárodní organizace práce).

Zároveň však nelze - spíše z pohledu vědecké terminologie - nevidět, že je silně problematické dané vykonávání práce nazývat homeworkem, když místem práce nemusí být př́mo domov - „home“ -, ale třeba ulice, kavárna či jiné veřejné prostranství atd. Přísně vzato by podle této logiky byl homeworkem každý obchodní cestující, podomní obchodník, pojištovací agent obcházející domácnosti apod. - vždyt přinejmenším většinu své pracovní doby stráví mimo pracoviště zaměstnavatele (ve skutečnosti ovšem rozhodně také mimo domov - alespoň svůj).

Podstatně přihodnějši pro př́pady, kdy je nutné zdůraznit, že pracovník nepracuje na pracovišti zaměstnavatele, je proto jiné, rovněž někdy používané označení outwork(ing), které zahrnuje všechny situace, kdy pracovník vykonává svou pracovní činnost mimo pracoviště svého zaměstnavatele - at jde o misto bydliš̌tě pracovníka (domov) nebo jakýkoli jiný prostor. ${ }^{18}$ Homeworkeři v klasickém smyslu v tomto sou-

15 Ještě zřetelnější je tento moment ve vztahu svobodných povolání a teleworku, kde je už formulace upozorňující na nutnou existenci jiného, většinového, běžnějšího pracovního prostredi zpravidla součástí charakteristiky a definice teleworku (viz napr̆. dále uváděné př́klady definic teleworku).

16 I tento aspekt je zřetelnější při komparaci svobodných povolání a teleworku (dalo by se říci, že v tom připadě dané konstatování platí dvojnásobně).

17 Bliže viz nap̌r. materiály dostupné na adrese www.eto.org.uk nebo www.eurofound.eu.int.

18 Nežridka jsou ovšem, bohužel, obě kategorie zaměňovány bez vniťnúho rozlišení, termíny homework a outwork jsou chápany v podstatě jako synonyma - obojí označuje práci mimo prostor zaměstnavatele, at už doma nebo jinde, čímž se terminologické nesrovnalosti pochopitelně nijak nevyjasňují. 
hrnu pochopitelně představují malý podíl (navíc se specifickými charakteristikami); podstatně větší část tvoǒ́ ti, kdo pracuji „,v terénu“: profesionální řidiči, stavební dělníci, montéri, opraváři a servisní pracovníci na místech nehod a poruch - i již zmínění obchodní cestující či pojištovací agenti.

\section{DISKUSE OKOLO DEFINICE HOMEWORKU V RÁMCI ILO}

Problematika homeworku není dnes v mezinárodním měřítku chápána ani jako přežitá (zejména díky její výrazné inovaci za využití nejnovějších komunikačních technologií), ani jako nedůležitá (např. vzhledem $\mathrm{k}$ odrazu podmínek zaměstnávání imigrantů coby homeworkerů na otázky dodržování lidských práv v zemi). Dủkazem toho může být i fakt, že od druhé poloviny 90 . let minulého století Mezinárodní organizace práce (ILO) za pomoci řady expertů pracuje na mezinárodní dohodě (úmluvě) o homeworku. Při koncipování předběžného obsahu a zejména hlavních zásad dohody bylo mimo jiné navrženo na základě rozsáhlé diskuse definovat homework následujícím způsobem: ${ }^{19}$

„a) termín 'homework' znamená práci vykonávanou osobou označovanou jako homeworker

i. ve svém domově nebo (za jiných předpokladů) na jiném místě, než je pracoviště zaměstnavatele podle svého vlastního výběru,

ii. za mzdu/plat,

iii. [práci - J. D.], která skončí produkty nebo službami specifikovanými zaměstnavatelem, bez ohledu na to, kdo poskytuje zařízení, materiál nebo jiné nutné 'vstupy', pokud tato osoba nemá stupeň samostatnosti a ekonomické nezávislosti nezbytné $\mathbf{k}$ tomu, aby byla pokládána za nezávislého pracujícího podle zákona, směrnic nebo soudního rozhodnutí,

b) termín 'zaměstnavatel' označuje osobu, fyzickou nebo právnickou, která bud' přímo nebo zprostředkovaně poskytuje práci."

Podle Rogera Blanpaina ${ }^{20}$, Pekka Huuhtanen ${ }^{21}$ a dalších autorů se $v$ rámci navrhovaného konceptu dohody o homeworku v kruzích ILO odehrála důležitá diskuse, která reflektovala predevším rozporné pohledy na žádoucí „šiřku“ optimální definice a rozporné interpretace možné aplikace této definice $\mathrm{v}$ praxi. Výše uvedený návrh definice homeworkera byl kritizován především ze dvou důvodů:

a) je zde nedostatečně odlišen homeworker a nezávisle nebo samostatně pracující člověk (v naší současné terminologii jde především o tzv. osoby samostatně činné), který svou pracovni činnost realizuje doma (část kritiků poukazovala prímo na to, že podle jejich názoru se zmíněná definice omezuje na zaměstnance a nepokrývá osoby samostatně pracující);

b) do jedné kategorie jsou zahrnuti jak tradiční homeworkeři, tak teleworkeři či jiní zaměstnanci pracující na dálku. ${ }^{22}$

19 BLANPAIN, R.: The legal and contractual situation of teleworkers in the European Union. The law aspects including self-employed. Consolidated Report; dostupné na www.eurofound.eu.int/publications/.

20 Tamtéž.

21 HUUHTANEN, P.: The Social Dimensions of Telework: The health and safety issues for teleworkers in the European Union. Consolidated Report; dostupné tamtéž.

22 Blíže k otázkám definice a klasifikace teleworkerủ viz následující kapitoly. 
V uvedeném prvním bodě kritiky se objevuje další skupina pracujících osob, u nichž může být sporné, existuje-li oprávnění řadit je jednoznačně mezi homeworkery, či nikoli, protože či přestože přinejmenším částečně pracují doma. Situace je obdobná jako u již zmíněné kategorie svobodných povolání, která se ostatně v mnoha případech může prolínat či překrývat s pracovníky „na volné noze“, s osobami pracujícími na živnostenský list, s prací kontraktorů na základě dohody o vykonání práce atd. - tedy se samostatně pracujícími osobami. V těchto skupinách jde o trochu jiný úhel pohledu: je to rozdíl mezi zaměstnancem (nějakého zaměstnavatele) a osobou samostatně činnou (která je sama sobě šéfem) - není to sice vlastní problém homeworku, ale jeho pojetí mohou úvahy s těmito otázkami spojené jistě ovlivnit.

Pro charakteristiku homeworku je na dané kritice významný ještě jiný moment. V obou zvlášt zmíněných případech (svobodná povolání a osoby samostatně činné) je podstatou nejasností a váhání nad jejich zařazením do kategorie homeworku v podstatě to, zda je lokalizace pracovního prostoru (domov) sama o sobě dostatečným kritériem pro vymezení homeworku, a v zákulisí za touto otázkou ještě problém, co je podstatou, základním určením, „klíčem“ homeworku. Zpravidla totiž definice a charakteristiky homeworku (event. domácí práce a dalších termínů používaných na úrovni synonym) konstatují, že homework (domácí práce) je práce, která ... Momentálně není tak důležité, jakou práci mají autoři na mysli a jaké její charakteristiky uvádějí jako zásadní; v dané souvislosti je podstatné, že v mnoha př́padech teoretikové nejdou $\mathrm{v}$ definici homeworku za kategorii práce - přitom o podstatě homeworku více a lépe vypovídá ne to, že je to práce (i když to je jistě pravda), ale že je to především způsob vykonávání práce, či přesněji způsob organizace práce (včetně podmínek, okolností atd.). Homework není zaměstnáním či profesí, je způsobem realizace zaměstnání, způsobem plnění pracovních úkolů, způsobem vykonávání profese - řekne-li někdo o sobě, že je homeworkerem, víme, jak a kde pracuje, ale nevíme vůbec nic o obsahu, náplni, zaměření, cílech jeho pracovní činnosti (dotyčný může být stejně dobře spisovatel jako účetní nebo sešivač suvenýrů a lepič obálek). Nic takového jako profesionální homeworker na úrovni povolání neexistuje, existují však různé profese vykonávané formou homeworku. ${ }^{23}$

\section{TELEWORK(ING) NEBOLI „PRÁCE NA DÁLKU“}

Termín telework(ing) stejně jako homework(ing) pochází z angličtiny, byt se v tomto př́padě nezapře neanglický původ první části slova (latinská předpona „tele“ znamenající „dálka“", „v dálce“). Telework se do češtiny obvykle překládá jako „práce na dálku“, z čehož mimo jiné vyplývá základní předběžná charakteristika teleworku: jde o vykonávání pracovní činnosti pracovníkem vzdáleným od svého zaměstnavatele, odběratele či zákazníka, o odevzdávání výsledkủ práce zaměstnavateli (odběrateli atd.) z jiného, „vzdáleného“ místa.

${ }^{23}$ V podstatě totéž platí i u teleworku - s jedinou výjimkou: telework už nebývá tak často charakterizován jako ,práce“, ale mnohem častěji jako „zpủsob organizace práce“. 
Pro takovýto způsob práce se v Evropě a zejména v rámci Evropské unie ${ }^{24}$ ustálil termín telework(ing), zatímco v USA je v synonymním významu používána kategorie telecommuting, ${ }^{25}$ což je možné přeložit jako „virtuální dojižděni““ (commuting $\mathrm{v}$ americké terminologii označuje každođenní dojiždění do práce). Jiným v angličtině (i americké) používaným rovnocenným termínem je především distance work (v češtině se „distančni práce“ jako synonymum teleworku uplatňuje často); v Evropě se kromě mezinárodně uznávaného pojmu teleworku používají v některých případech také „národní varianty“ tohoto termínu: např. ve Francii télétravail či v Itálii telelavoro. ${ }^{26}$

Vykonávat práci na určitou vzdálenost od místa, kde je obvykle (či spíše doposud tradičně) vykonávána, je jedním (prvním) nezbytným obecně uznávaným atributem teleworku - při posuzování charakteru a způsobu práce je to kritérium nutné, nikoli však dostačující. Druhým nezbytným obecně uznávaným atributem teleworku je technická stránka spojení na dálku: koncept teleworku se u drtivé většiny autorů takřka automaticky (a přitom nijak zásadně logicky) spojuje s využiváním informačních a komunikačních technologií (ICT - Information and Communications Technologies), zejména nejnovějšího typu. Zdá se dokonce, že práce na dálku za použití takových komunikačních technik, jako je telegraf a i telefon (s výjimkou mobilního), je z dnešního hlediska posuzována jen jako jakýsi prototyp teleworku, možno říci ,tradiční telework“ (v analogii k „tradičnímu homeworku“) a skutečný, „pravý“ telework jako by začinal až po rozšǐřeni použivání (osobního) počítače, faxu, e-mailu, mobilního telefonu, videokonferencí, internetu atd.

$\mathrm{K}$ tomu, aby bylo možné určitou pracovní situaci označit za telework, je třeba, aby byla splněna obě dvě kritéria teleworku současně: člověk musí pracovat na dálku a za využití moderních informačních a komunikačních technologií. Proto je sporná opráv-

${ }^{24}$ O popularizaci daného termínu v Evropě se údajně nejvíce zasloužila právě Evropská unie, která jej systematicky použivala ve svých dosti intenzivních snahách o zkoumání jeho souvislostí a dủsledkủ v praxi (Evropská unie např. financovala významná zkoumání teleworku orientovaná především na jeho využití coby prostředku rozvoje ekonomické aktivity v souvislosti s možností vytvářet pracovni přiležitosti ve venkovských oblastech nebo $\mathrm{v}$ lokalitách s ekonomickými problémy).

25 Málokterý ze zahraničních materiálủ zahrnující i základní pojmosloví v dané oblasti zapomene připomenout, že tento termín razil zhruba od r. 1973 Jack Nilles, který hrál klíčovou roli v zavedení přislušného konceptu v USA, a zpopularizoval futurista FrancIS KINSMAN ve své knize Telecommuters (John Wiley and Sons 1987). J. Nilles je, mimochodem, také tvĭrcem termínu a predstavy edifice complex. Firmy budují pro sebe honosná sídla, která mají svou očividnou nákladností a vnější okázalostí reprezentovat jejich dosavadní úspěchy i nadějný potenciál do budoucna, trpí ,komplexem velkých budov“. Lze dodat, že právě telework mủže být jedním z lékủ, který pomůže tyto firmy z jejich komplexu vyléčit (jiná otázka ovšem je, zda právě takovéto firmy o vyléčení stojí).

26 Zde se pochopitelně nabízi otázka, proč čeština nenásleduje tyto př́klady - až na ojedinělé a zpravidla jakoby nepřiliš vážně míněné pokusy - zavedením termínu ,telepráce“ (analogicky využitím latinské předložky u slov jako je ,televize“ a „telekomunikace“, která u nás naprosto zdomácněla, aniž by dnes - vyvolávala rozruch a sváděla $\mathrm{k}$ opravdu laciné slovní hř́čce). Dosti kuriózní je pak situace citovaná v článku A. Svobody: „Možná jste ještě neslyšeli tajemná slova jako teleworking nebo telecommuting, ale asi byste si jen těžko mysleli, že se jedná o práci pro mladá telátka. Dủvod je asi trochu jiný, v našich zemích nebyly až do nedávné doby přiliš vhodné podmínky na rozvoj tohoto druhu práce na dálku. Trochu jiný názor však mají zástupci evropské teleworkingové organizace, kteří se domnívaji, že hlavním dủvodem, proč je teleworking u nás nepopulární, je právě již v titulku zmiňovaná souvislost s mládaty jednoho velice užitečného domácího zvírete. Je sice pravda, že vycházeji z jednoho českého zdroje věnovaného teleworkingu, ale já doufám, že se jednalo jen o vtip, který evropšti komisaři nepochopili a že nejsme taková te...., abychom si mysleli, že telecommuting se hodí jedině na pastvu“ (SvoBoDA, A.: Je teleworking prací pro dobytek? Computer World 31, 2000; dostupné na www.cw.cz/cw.archiv.nsf/0/). 
něnost použivání $\mathrm{v}$ poslední době stále populárnějšího termínu $e$-Work ${ }^{27}$ ( $E$-work) jakožto synonyma teleworku ${ }^{28}$. Problematičnost položení rovnítka mezi e-Work (v jeho běžném většinovém pojetí) a telework spočívá především $\mathrm{v}$ tom, že $e$-Work se obdobně jako $e$-Commerce nebo $e$-Learning. (či e-Government, e-Procurement, případně „e-občanství,“ „e-hlasování“ ${ }^{29}$ ) vztahuje $\mathrm{k}$ jakési velmi pokročilé elektronizaci či spíše komputerizaci a „internetizaci“ svého objektu, tj. k práci, obchodování nebo učení za využití (osobních) počítačů, internetu, specializovaného softwaru, různých programů a aplikací. Zároveň ale $\mathrm{v}$ př̀dstavě $e$-Worku není řešena otázka umístění té které činnosti, přesněji řečeno její nutné „vzdálenosti“ od místa, kde se tato činnost běžně provozuje, což je právě u teleworku podstatnou charakteristikou ${ }^{30}$ - pracovat za pomoci počítače, internetu a dalšich přístrojů, programů a funkcí je možné i při každodenním dojiždění do zaměstnání ve zcela tradiční kanceláŕi mezi řadou kolegů a za bezprostředního dohledu zaměstnavatele (byt se podklady pro práci vyhledávají na intranetu, její výsledky se předávají na disketách či CD-ROMech a s kolegy sedícími u stolu vzdáleného dva metry se koresponduje e-mailem).

Nutnost spojit faktor vymezené lokalizace pracovni činnosti (,v dálce“) a faktor informační a komunikační technologie (ICT) se objevuje v drtivé většině dosavadních pokusů o definování teleworku a dokonce bývá často výslovné upozornění na nezbytnou současnou koexistenci obou těchto faktori̊ připojováno $\mathrm{k}$ definici jako její součást. Podle Pekka Huuhtanena (autora jedné ze souhrnných studií Evropského fondu pro zdokonalení životních a pracovních podmínek, která obsahuje mimo jiné přehlèd vybraných národních definic teleworku) většina národních zpráv zabývajících se situací a podmínkami teleworku $\mathrm{v}$ jednotlivých evropských zemích jmenovitě uvádí při svém funkčním definování teleworku ${ }^{31}$ dva prvky: „místo práce, využívání telekomu-

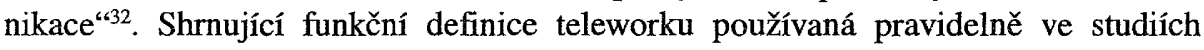

27 Tento termín odvozený ze sousloví electronic Work vznikl na konci 90 . let minulého století - poněkud paradoxně jako vyhraněně odmítavá reakce na přilišné uživání (naduživání, zneužíváni) slova „telework“ v rámci spammingu a již dřive zmíněného tzv. MLM-systému při nabídce a prodeji sporných a často př́imo podvodných metod na téma ,jak rychle zbohatnout $\mathrm{z}$ domova“. (Jistě není podobností čistě náhodnou fakt, že právě tento charakter má celá řada - možno říci výrazná většina - nabídek $v$ inzerátech na téma homework a telework $v$ našich současných médiích včetně internetu.)

28 To platí i o některých dalších termínech, které se čas od času objevují jako synonyma teleworku - některé $z$ nich postihuji jen určitou část či formu teleworku, jiné naopak zachycují obecnější trendy v současných změnách práce a netýkají se jen teleworku, $v$ daném textu nejsou tedy jako synonyma teleworku chápány (např. redukující pojmy jako electronic homework a electronic cottage, nebo naopak široké a obecné kategorie typu flexi-place nebo networking).

29 Termíny viz Peterka, J. - Veselý, V.: Tři pilǐre na podporu znalostní ekonomiky. Návrh $k$ veřejné dis$k u s i$; dostupné na www.park.czlarticle.asp?sec=3.

30 Logicky oprávněné je v tomto připadě např pojetí P. Batese a U. Huwsové, kteři jako druh teleworku (konkr. jako tele-homeworking) vymezují nikoli samotný e-Work, ale pouze e-Work plně realizovaný $z$ domova (BATES, P. - Huws, U.: Modelling eWork in Europe. Estimates, models and forecasts from the EMERGENCE project. IES Report 388, 2002; dostupné na www.employment-studies.co.uk).

31 O pouze ,funkčním definování teleworku“ hovořil Roger Blanpain v souvislosti s tím, že v raade evropských zemí - soudě podle zmíněných národních zpráv - telework (ještě) není legální kategorií, a není tedy možné předjimat oficiální definici teleworku. (BLANPAIN, R.: The legal and contractual situation of teleworkers in the European Union. The law aspects including self-employed. Consolidated Report; dostupné na www.eurofound.eu.int/publications/files/WP9728EN.pdf).

32 HuUHTANEN, P.: The Social Dimensions of Telework: The health and safety issues for teleworkers in the European Union. Consolidated Report; dostupné na www.eurofound.eu.int/publications/files/. Obdobné pasáže obsahuji i dalši zprávy stejné instituce, např. BLANPAIN, R.: The legal and contractual situation of teleworkers in the European Union. The law aspects including self-employed. Consolidated Report; dostupné na www.eurofound.eu.int/publications/files/WP9728EN.pdf. 
Evropského fondu pro zdokonalení životních a pracovních podmínek, jejímž autorem je Roger Blanpain, potom zní takto: „Telework je práce vykonávaná teleworkerem (zaměstnanec, samostatně pracující, homeworker...) pro zaměstnavatele nebo zákazníka z převážné nebo významné části [pracovní doby - pozn. J. D.] na místě jiném, než

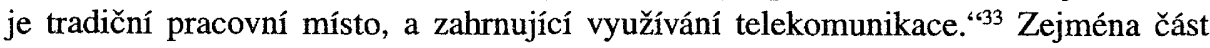
týkající se možných technických prostředků pak rozvijí nap̌̌. definice A. Graye et al. z r. 1994: „Teleworking nebo telecommuting je flexibilní způsob organizace práce bez potřeby fyzické př́tomnosti pracovníka na jeho pracovním místě během podstatných částí jeho pracovní doby. Profesní aktivita teleworkerủ v sobě zahrnuje běžné využívání technik elektronického zpracování informací a rozsáhlé využivání telekomunikačních zařízení (telefon, záznamník, fax, počítač, připojení $\mathrm{k}$ síti a další rozvinuté telekomunikační služby, jako je ISDN, hlasová schránka, audio- a videokonference, přesměrování hovorủ, mobilní telefon atd.). ${ }^{\text {“34 }}$

Ve stejném základním duchu pojednávají o teleworku i dokumenty drtivé většiny oficiálních mezinárodních institucí zabývající se teleworkem a zejména jeho vymezením a podmínkami $\mathrm{z}$ hlediska pracovního práva - telework je totiž mimo jiné i novou formou pracovněprávních vztahů (což je momentálně základní vysoce aktuální otázka a úkol nikoli jen $\mathrm{z}$ hlediska teorie, ale především $\mathrm{z}$ hlediska praxe). Např. v Evropské chartě o teleworku z června 1997 se telework vymezuje jako „způsob práce mimo své obvyklé pracovní místo výhradně díky informačním a komunikačním technologiím“ “. ${ }^{35}$ Velmi známá a rozšǐřená je také definice organizace $\mathrm{ETO}^{36}$, v níž se konstatuje, že společným elementem prolínajícím všechny aspekty teleworku je „využití počítačủ a telekomunikace ke změně príjaté [doposud platné - pozn. J. D.] geografie práce ${ }^{\text {“ }} \cdot{ }^{37}$ A konečně třetí příklad: v Rámcové dohodě o teleworku z července 2002 se představitelé „,sociálních partnerü“, tj. zaměstnancủ a odborářu ${ }^{38} \mathrm{v}$ rámci Evropské unie shodli na tom, že telework je „forma organizace a/nebo realizace práce využívající informační technologie $v$ rámci pracovní smlouvy nebo pracovního poměru, $v$ němž práce, která by mohla být stejně tak vykonávána v místě zaměstnavatele, je prováděna mimo tato obvyklá místa“. 39

33 BLANPAIN, R.: The legal and contractual situation of teleworkers in the European Union. The law aspects including self-employed. Consolidated Report; dostupné na www.eurofound.eu.int/publications/files/WP9728EN.pdf.

34 Citováno podle: M. BARYLAK: Telework; dostupné na www.vilspa.esa.es/staff/iue/.

35 La Charte Européenne du Travail a Distance, dostupné na rad2000.free.fr/chareuro.htm.

36 ETO je zkratka pro European Telework Online, internetový portál o teleworku a telecommutingu fungující od r. 1996 na adrese www.eto.org. (existuji i národní jazykové verze tohoto portálu - česká verze nese název European Telework Online Ceská republika a její internetová adresa zní www.eto.org.uk/nat/cz/index.cz.htm).

37 www.eto.org.uk.

38 Dne 16. 7. 2002 byla po osmi měsících jednání podepsána Rámcová dohoda o práci na dálku, která bude implementována na národních úrovních členskými organizacemi a ne prostřednictvím evropské legislativy, jako bylo doposud obvyklé u jiných rámcových dohod. Dohodu podepsali: ETUC - Evropská odborová konfederace; UNICE - Unie prümyslových a zaměstnavatelských svazů Evropy; UEAPME - Unie malých a středních podnikủ Evropy; CEEP - Evropské středisko pro podniky se státní účastí a podniky veřejného hospodářského zájmu.

39 Accord-cadre sur le télétravail; dostupné na www.teletravailonline.com. $\mathrm{Z}$ textu této dohody je však také patrný specifický úhel pohledu zainteresovaných institucí - telework je zde vymezen (kromě výše uvedeného obecného definování) $i$ jako ,prostředek podnikủ a organizaci veřejných služeb $\mathrm{k}$ modernizaci organizace práce a prostředek pracovníkủ ke sladění života profesního a sociálního a $\mathbf{k}$ získání větší autonomie $v$ plnění pracovních úkolứ“ (tamtéž). Sociálněpracovní, či přimo odborářskopracovní kontext je zde zřejmý, dủležité zde není jen vymezení podstaty teleworku, ale rovněž jeho možné funkce pro podniky a zaměstnance. 
V našich podmínkách se obvykle odkazuje na tuto definici teleworku, která se ovšem obsahově nijak neliší od výše uváděných vymezení: „Pracovní místo (aby se jednalo o teleworking) musí být jiné než běžné pracovní místo u zaměstnavatele. Informační a telekomunikační technologie a jejich využití jsou potom charakteristickým a nezbytným rysem takovéhoto způsobu práce. “ ${ }^{40}$

\section{TELEWORK NOMÁDSKÝ, ALTERNUJÍCÍ, DOPLŇKOVÝ A JINÝ}

Mezi přiklady typických činností a profesí, které jsou vhodné pro telework, nepochybně patří následující: překlady, výzkumné a vývojové práce, poradenská činnost, zpracování různých analýz a projektů, práce obchodních zástupcủ, auditorů a novinářů, servis horkých linek, účetnictví, konstrukční a návrhářské práce, kalkulace, zpracování objednávek, fakturace a statistika, korektury, vědecké a literární aktivity, redakční práce, informatické služby, grafické práce, manažerská práce. Samostatnou kapitolou jsou pak pracovní činnosti související bezprostředně s počítači a internetem už nejenom jako prostředkem komunikace, ale přimo „objektem“ a „předmětem“ pracovní činnosti - např. programátorské práce, počítačové zpracování informací, tvorba či správa databází, webdesign atd. Jak je patrné $\mathrm{z}$ vyjmenovaných príkladů, $\mathrm{z}$ velké části jde o kvalifikované, často vysoce kvalifikované tzv. znalostní pracovníky (knowledge workers), dnes někdy označované jako „zlaté límečky““. ${ }^{41}$ Rada uvedených profesních činností samých není žádnou novinkou (samozřejmě kromě vlastních počítačových a internetových aktivit) a některé $\mathrm{z}$ nich byly i dřive vykonávány mimo prostory zaměstnavatele (např. obchodní zástupci a spisovatelé), dokonce výsledky některých aktivit byly $\mathrm{v}$ minulosti zaměstnavateli či zákazníkovi zprostředkovávány komunikační technikou (třeba novináŕ diktující přes telefon svou reportáž z New Yorku do londýnské redakce svých novin). Nicméně prostředky moderní informační a komunikační technologie a možnosti jejich využití posunuly dané činnosti na jinou rovinu. Lze říci, že mnoho uvedených činností není nutno vykonávat pouze a výhradně na dálku a za pomoci počítačủ či internetu, ale právě moderní ICT jsou pro jejich realizaci zvláště vhodné a výhodné - tyto činnosti nevznikly na základě a v důsledku ICT, ale $\mathrm{s}$ její pomocí a jejím prostřednictvím změnily svou dřive existující podobu (a v důsledku toho často došlo i k mírnému posunutí obsahu).

Daný náhodný výčet př́kladů dává tušit, že telework nebude jednotnou kategorií, ale že naopak může mít celou řadu podob podle požadavků a potřeb různých konkrétních pracovních činností a pracovních úkolů.

$\mathrm{V}$ mnoha typologiích a klasifikacích teleworku se objevuje především odlišení teleworkerů-zaměstnanců (employed teleworkers) a samostatných teleworkerủ („na volné noze“, samostatně činných - self-employed teleworkers, entrepreneurial teleworkers), drtivá většina dokumentů dnes již dovoluje považovat jak zaměstnance, tak samostat-

${ }^{40}$ Diskuse k teleworkingu, Hradec Králové, 24. 3. 2003, ISSS 2003; dostupné na http://216.239.59.104/ search?q=cache:rA7WvWuxwO8J:www.isss.cz/download/prezentace/kucera_spis.ppt+teleworking\&hl=cs \&lr=lang_cs\&ie=UTF-8; KROFT, M. - KUČERA, A. aj.: Teleworking. Materiál předkládaný ministru práce a sociálních věcí CR. 2002; dostupné na www.spis.cz/spis/SPIS.home.

${ }^{41}$ HYNEK, J.: Ceká nás práce na dálku?? Moderní řizení; dostupné na Modernirizeni.ihned.cz/3-13057940teleworking-600000_detail-0d. 
né pracovníky za teleworkery. ${ }^{42} \mathrm{Na}$ to může navazovat občas i detailnější dělení teleworkerů podle toho, kdo vlastní jejich výrobní prostředky a platí provozní náklady (pracovník, zaměstnavatel, třetí osoba), pro koho pracují (zaměstnavatel či klient, event. více klientů) apod. Např. v materiálu předkládaném organizaci SPIS ministru práce a sociálních věcí ČR se o různých variantách teleworku uvažuje hlavně na úrovni kombinace „tři podstatných rysủ, které charakterizují jednotlivé způsoby výkonu práce:

(a) kdo vlastní prostředky, se kterými pracovník pracuje, s jejichž pomocí práci vykonává,

(b) kdo vlastní objekt, kde práci vykonává,

(c) kdo pracovníkovi práci zadává a kdo jeho práci kontroluje a kolik těchto zadavatelů práce je". ${ }^{43}$

$\mathrm{V}$ obecné typologizaci můžeme odlišit od samého teleworku jednak teletrade (obchodování na dálku), jednak telecooperation (práce ve virtuálním týmu).

Teletrade je „Široký pojem, který může znamenat např. obchodního cestujícího $s$ notebookem a mobilním telefonem, který je díky připojení na podnikový informační systém dokonale seznámen s aktuálním stavem zboží na skladě a jeho cenami. Do podobné kategorie patří i různí servisní technici, kteři prostřednictvím technologií přijímají a posléze i uzavírají zakázky. Svým způsobem do této kategorie patří vlastně i elektronický obchod (...)“.44

Telecooperation je - na rozdíl od teleworku a teletrade, které přece jen mají své prototypy $v$ minulosti - zcela novou formou, jejiž princip spočívá $v$ tom, že ,pro řešení konkrétního úkolu je určen tým lidí profesně odpovídajících definovaným požadavkủm. Tento zpủsob práce je dnes charakteristický převážně pro poradenské firmy, které mohou tímto způsobem angažovat specialisty $z$ celého světa. Pracovníci mají obvykle spolu spojení přes firemní extranety, Internet nebo (v horším případě) využívaji některý $\mathrm{z}$ groupwarových programů. Technicky jde asi o nejnáročnější způsob práce na dálku, jeho součástí bývají i videokonference. Podobně mohou spolupracovat i programátoři nebo vývojáři. Nespornou výhodou pro firmy je možnost angažovat obvykle velmi drahé specialisty pouze na nezbytně dlouhou dobu“. ${ }^{45}$

Jen částečně tuto klasifikaci připomíná jiné členění teleworku, a to podle typu místa, kde pracovník nejvíce pracuje a tráví největší část svého pracovního času: základními variantami jsou telework $\mathrm{z}$ domova (viz bliže následující samostatná kapitola), telework z telecentra (s ním související telecottage a televillage) a mobilní (nomádský, kočovný) telework.

Telecentra jsou ,zařízení, která byla založena pro komerční účely. Obvykle poskytují pracoviště lidem, kteři jsou zaměstnáni na plný úvazek a chtějí pracovat mimo hlavní kancelář zaměstnavatele, ale nechtějí nebo nemohou pracovat doma. (...) tele-

42 Problém zde má stejné zadání a stejnou logiku argumentủ jako obdobná sporná situace u homeworku (viz výše hlavně kapitola 5.; diskuse okolo definice homeworku v rámci ILO).

43 KROFT, M. - KUCERA, A. aj.: Teleworking. Materiál předkládaný ministru práce a sociálních věcí Čr. 2002; dostupné na www.spis.cz/spis/SPIS.home.

44 RUŚCAKOVA, D.: Teleworking - práce pro ukázněné. Computer. World 12, 2001; dostupné na www.cw.cz/cwarchiv.nsf/0/.

45 Tamtéž. 
centra kladou velký důraz na poskytování pracoviště s vyspělými informačními technologiemi a sítovým připojením. Telecentra mohou být kompletně vlastněna určitou společností nebo mohou mít jednotlivé společnosti pronajaty $\mathrm{v}$ telecentru pouze část prostor. Ve stručnosti múžeme tedy říci, že telecentra jsou zařízení, která kladou dưraz na poskytování dobře organizovaného, bezpečného a klidného pracovního prostředí pro lidi, kteři potřebují místo, kde mohou vykonávat své zaměstnání a být snadno spojeni se svým zaměstnavatelem, kolegy, zákazníky atd." ${ }^{46} \mathrm{~V}$ každodenní praxi to vypadá tak, že každý zaměstnanec podniku pracujícího alespoň částečně $s$ využitím telecenter cestuje do té kanceláře sítě telecenter, která je pro něj nejbližší nebo z hlediska cestování nejdostupnější, a tam se potom zapoji prostřednictvím ICT do práce týmu, jehož další členové obdobně pracují z jiných telecenter, event. $\mathrm{z}$ hlavních pracovních prostor zaměstnavatele. Určitými rysy může telework $\mathrm{z}$ telecentra sice připomínat výše zmíněnou formu telecooperation, ale zásadní rozdíl je $\mathrm{v}$ tom, že $\mathrm{z}$ telecenter mohou pracovat a také pracují stálí zaměstnanci firem, nikoli jen dočasní pracovníci vybraní pro jeden úkol (princip práce je ovšem stejný). Pro telework realizující se víceméně výlučně v nějakém takovémto centru se používá také označení centre-based telework. ${ }^{47}$

Hlavním charakteristikám telecentra odpovídají do značné míry i „satelitní kancelář“ (satellite office - detašované pracoviště firmy vybavené odpovídajícími prostředky ICT umístěné mimo hlavní pracoviště firmy v jiné části města, na jeho okraji nebo i v jiném regionu), ,kancelář v sousedstvi““ (neigborough centres - společná detašovaná pracoviště více zaměstnavatelů, kanceláře $\mathrm{v}$ obytných čtvrtích nebo na okrajích měst, v nichž ,na dálku“ pracují společně zaměstnanci různých firem) nebo hotdesking či hotelling ( $v$ rámci širšího kancelařrského servisu místo u pracovního stolu s počítačovým vybavením, kde se podle svých pracovních potřeb stř́idaji různí pracovníci; jakýsi přechodný hotel, nikoli pro přespání, ale pro práci nebo přinejmenším pro kontakt se zaměstnavatelem či klientem a elektronické odeslání výsledkủ práce). Za splnění určitých podmínek jsou tyto „kanceláře“ konkrétními podobami telecentra (nikoli však nutně automaticky).

$\mathrm{V}$ jistém smyslu speciálním př́padem telecenter jsou telecottage ${ }^{48}$ která jsou umístěna zásadně ve venkovských oblastech, kde poskytuji většinou jen určitý druh služeb souvisejících bezprostředně $s$ počítači, počítačovou gramotností a s nimi spjatých aktivit (organizace počítačových kurzů obecných i specializovaných na určité činnosti a určité aplikace, práce s e-mailem a internetem apod.), případně i se samotným teleworkem (obyvatelé venkova takto mohou najít a realizovat zaměstnání formou teleworku).

$\mathrm{Na}$ ideu telecottage navazuje a rozviji jeji principy forma televillage. $\mathrm{V}$ tomto př́padě jde také o záležitost venkova, ${ }^{49}$ ale televillage je určena pro masovou aktivitu

${ }^{46}$ Základní formy teleworku; dostupné na athena.zcu.cz/batcos/demo_cz/.

47 Viz např. dokument organizace EcaTT z r. 2000 nazvaný On new Ways of Working and new Forms of Business across Europe.

48 Název odvozený $\mathrm{z}$ anglického slova ,cottage“ (= chalupa) poukazuje na venkov, vesnici jakožto původní místo své existence i její účel: pưvodním cílem telecottage bylo „přnést technologii a odpovídající dovednosti lidem ve vzdálených vesnicích, kteři nemaji dostatek přiležitostí získat tyto dovednosti při práci pro 'hi-tech' zaměstnavatele, kteři obvykle sídlí ve velkých městech" (Základni formy teleworku; dostupné na athena.zcu.cz/batcos/demo_cz/.).

49 Termín televillage je odvozen od anglického slova „village“, tj. vesnice. 
a komplexní životní styl: celá vesnice je „propojena kabely a každý dům je plně vybaven vnitřní sítí, která je přpojena $k$ síti vesnice a prostřednictvím širokopásmových komunikací ke 'globální vesnici'. Tato myšlenka je velmi zajímavá a je vhodná pro skupinu motivovaných lidí, kteři chtějí kombinovat vesnický životní styl s perfektním př́stupem $\mathrm{k}$ 'informační dálnici'“. .50

Mobilní (nomádský, event. kočovný) telework se vyznačuje v první řadě - odtud název - bud značnou mírou služebních, pracovních cest, nebo dokonce $\mathrm{v}$ řadě př́ipadů spíše vysloveně mobilním, „cestovním“ (,putovním“) charakterem výkonu príslušné profesní činnosti fakticky bez jednoho fixního pracovního prostoru (práce na cestách -

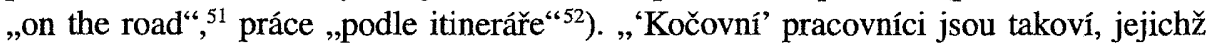
pracovní činnost vyžaduje významný podíl cestování, nebot jejich pracoviště je vždy tam, kde je potřeba. Př́kladem mohou být prodejci nebo servisní inženýři. Může se také jednat o vedoucí pracovníky, kteři cestují s notebookem a mobilním telefonem a chtějí využít všechna zařizeni, která může moderní technologie nabídnout, jako např. hlasové a faxové poštovní schránky, posílání zpráv, vzdálený př́stup apod. Tito pracovníci mohou pracovat kdekoliv - $\mathrm{v}$ hotelu, $\mathrm{v}$ autě, na palubě letadla apod. Kočovní teleworkeři obvykle mají alespoň nějaké kancelářské vybavení doma, ale nejdůležitější pro ně je, aby měli přistup ke všem potřebným zařízením, když jsou na cestách. " 53

Vétšina pojetí teleworku zdủrazňuje, že teleworker pracuje „na dálku“ větší nebo významnější část své pracovní doby ( $\mathrm{v}$ žádném př́ípadě tedy nejde o naprosto direktivní určení platné pro plnou pracovní dobu nebo pro splnění celého pracovního úkolu). V rámci teleworku se pak vydělují dvě specifické formy pravidelnébo střídání pracovního prostředí, přesněji řečeno střídání výkonu práce ve firmě (kancelárii, instituci, organizaci atd.) a vykonávání profesní činnosti v prostředí domova, event. v nějakém typu telecentra. Multi-site telework označuje obecně situaci, kdy pracovník střídá práci v kancelárí a na jiném místě či místech (zpravidla bư domov, nebo telecentrum, případně obojí) - pracovník tedy „sedává na více židlích“ ( $v$ tomto případě myšleno spiše doslova než $\mathrm{v}$ přeneseném slova smyslu). $\mathrm{V}$ případě teleworku tzv. střídavého, alternujícího (alternating telework) či kyvadlového, pendlovacího (télépendulaire ${ }^{54}$ ) rozděluje pracovník pomyslně své úkoly na dvě části, z nichž jednu vykonává v kanceláři (firmě, podniku atd.) a druhou doma. Tzv. doplňkový, přidavný (supplementary) telework označuje situaci, kdy člověk sice pracuje především a „kmenově“ ve firmě (podniku, instituci), ale ad hoc podle potřeby, víceméně nárazově, doplňuje tuto práci v kancelárí i prací doma. U tohoto vlastně jen „nahodilého" či „občasného" teleworkera vyslovuje řada autorů značné rozpaky nad tím, zda ho vůbec mezi teleworkery řadit (z hlediska pracovních podmínek apod.). ${ }^{55}$

50 Tamtéž

51 BLANPAIN, R.: The legal and contractual situation of teleworkers in the European Union. The law aspects including self-employed. Consolidated Report; dostupné na www.eurofound.eu.int/publications/ files/WP9728EN.pdf; What are Telework, Teletrade and Telecooperation?, dostupné na www.eto. org.uk/work.

52 www.teletravailonline.com.

53 Základni formy teleworku; dostupné na athena.zcu.cz/batcos/demo_cz/.

54 Termin viz napr. www.teletravailonline.com.

55 TELEWORK Data Report (Population Survey). Ten Countries in Comparison. Bonn 2000; dostupné na

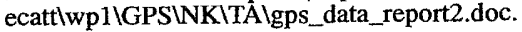




\section{TELE-HOMEWORK(ING) NEBOLI „PRÁCE NA DÁLKU Z DOMOVA“}

Východiskem $\mathrm{k}$ charakteristice posledního důležitého a zatím nezmíněného typu teleworku, který je možné označit za pojetí teleworku v užším významu (vzhledem $\mathrm{k}$ rozšiřrenosti této představy ve veřejném mínění a vzhledem $\mathrm{k}$ jeho postavení jakožto symbolu teleworku obecně a všech rozmanitých variant teleworku), je vzájemný vztah homeworku a teleworku.

Je zajímavé, že - jak již bylo řečeno - telework se u drtivé většiny autorů takřka automaticky a přitom nijak zásadně logicky spojuje s využíváním ICT, zejména nejnovějšího typu. Přitom pokud bychom byli skutečně důslední, můžeme i klasické druhy homeworku chápat jako práci, kterou pracovník vykonává odděleně od svého zaměstnavatele (či klienta, zákazníka) a jeho pracovních prostor a nějak mu její výsledky přes danou vzdálenost distribuuje (často i prostřednictvím komunikační techniky, byt ne právě té, která se shrnuje do kategorie moderní ICT).

Obdobné úvahy zřejmě také vedly některé autory $\mathrm{k}$ nadřazování homeworku nad teleworkem: homework je obecnější kategorií a telework je tím speciálním případem homeworku, kdy člověk ke své práci doma využívá v hojné miứe moderni ICT. Jiní autoři však tuto logiku interpretují přesně obráceně: telework je chápán jako obecnější situace - člověk pracuje mimo prostory svého zaměstnavatele (klienta, zákazníka), jemuž pomocí určitých telekomunikačních prostředků předává výsledky své práce, zatímco homework poukazuje jen na jednu z konkrétních možností prostoru, kde lze pracovní činnost vykonávat (každý homework je tedy v rámci této představy zároveň teleworkem). ${ }^{56} \mathrm{~A}$ konečně existuje i skupina autorỉ, kteři homework s teleworkem jednoduše ztotožňuji ${ }^{57}$ což je bohužel situace nikoli neobvyklá právě v našich podmínkách. ${ }^{58}$

56 Tuto představu lze vysledovat např. v této citaci: ,(...) se zaměříme na homework, který je v současnosti nejběžnějším způsobem práce na dálku“ (Základni formy teleworku; dostupné na athena.zcu.cz/batcos/demo_cz/).

57 Tato skutečnost je patrná napr. z následujících citátů: „Teleworking (telecommuting, homeworking) je trend zaměstnání na dálku, který je umožněn rozvojem moderních informačních a komunikačních technologií“ (KROFT, M. - KUČERA, A. aj.: Teleworking. Materiál předkládaný ministru práce a sociálních věci CR. 2002; dostupné na www.spis.cz/spis/SPIS.home); ,Distanční práce (práce na dálku, homeworking) je velmi nadějnou, rychle se rozvíjející formou organizace práce" (HƯTTLoVÁ, E.: Distanční práce zajímá zaměstnance $i$ zaměstnavatele; dostupné na www.vse.cz).

58 Při ztotožñováni homeworku a teleworku nejsou pochopitelně homeworkeři a teleworkeři odlišováni a jsou označováni souhrnně (v našich podmínkách) jako „,domáčtí zaměstnanci“, což mủže pủsobit zmatečně v pracovněprávních souvislostech $-\mathrm{z}$ hlediska pracovnich podminek by se totiž teleworkeři podle dosavadního (funkčního) pojetí ve většině evropských zemí měli podobat spíše „běžným pracovníkủm“ než homeworkerům s jejich určitými modifikacemi práv a povinností (naše stávající pracovní právo se zabývá kategorii homeworkerủ pod označením domáčti pracovníci, ale nezná kategorii teleworkerů). Obdobně se bohužel konstatuje i ve výkladové přiručce pracovního práva (ale už z roku 1997): ,Domáčtí zaměstnanci jsou ti, kteří podle pracovní smlouvy pravidelně konají práci ve svém bydlišti či jinde, avšak mimo pracoviště svého či jiného zaměstnavatele" (BĚLINA, M., a kol.: Pracovní právo. Praha, Spolek čs. právníkủ Všehrd 1997, s. 143), Vysvětlením dané nepřesné terminologie (která mủže být ovšem na právní rovině značně nebezpečná) je snad skutečnost, že v našich podmínkách je telework ve všech svých podobách ještě tak nerozvinutý, že vyčkání na nový mezinárodní Kodex práce, který se zabývá i těmito otázkami, nemủže mít nijak dalekosáhlé následky. Logické by prozatím bylo řešit situaci v naši praxi rủzně: „Na rozdíl od homeworkingu, jehož existenci zákoník práce výslovně v několika svých ustanoveních pripouští a upravuje, úprava teleworkingu neexistuje. S ohledem na pojmové znaky teleworkingu a skutečnost, že místo výkonu práce lze považovat za dohodnuté i v takových připadech, kdy není $\mathrm{v}$ pracovní smlouvě výslovně sjednáno, řidi se pracovní poměry těchto zaměstnancủ v plném rozsahu zákoníkem práce, avšak s ohledem na určitá specifika, které vyplývaji z povahy práce“ (MATEJKA, J.: Distančni výkon práce a jeho právni úprava; dostupné na www.lupa.cz). Clověk však u nás mǔže praco- 
Dnes se oprávněně prosazuje přístup, který chápe homework a telework jako dva v základním principu se odlišující samostatné typy organizace práce, specifické případy tzv. atypických pracovních poměrů (u zaměstnanců). Základní diference vyplývá již z výše uvedených etymologických a definičních úvah - stručně a výstižně ji lze shrnout takto: „Rozdíl lze spatřovat v tom, že 'homeworking' je pojmově vázán na působení $v$ místě svého bydliště, bez ohledu na povahu práce, zatímco 'teleworking' naopak vychází ze způsobu provádění práce (na dálku, prostřednictvím informačních a telekomunikačních technologií), bez ohledu na skutečné místo, kde k tomu dochází. “59

Přesto mají homework a telework pochopitelně mnoho společného, či přesněji řečeno obdobného; existuje dokonce př́pad, který je současně homeworkem i teleworkem: v angličtině se označuje termínem home based teleworking (home-based telework) nebo tele-homeworking (analogicky je možno i home-teleworking). Teprve tento průsečík homeworku a teleworku odpovídá - po širokém vějiři všech předchozích jiných variant - představě většině lidí o teleworku: „Typický teleworker tedy ráno v papučích usedne do pohodlného křesla ve své domácí pracovně, zapne počítač (není vyloučeno, že si vyhrne rukávy) a pustí se do práce. Se svými nadřízenými či kolegy komunikuje prostřednictvím internetu, touto cestou také přijímá a odesílá potřebná data." 60

Je tedy patrné, že se v obecném povědomí, veřejném mínění objevuje především poněkud zkreslená a dosti zjednodušující představa teleworku - tele-homework je sice velmi často využívanou, ale rozhodně nikoli jedinou formou teleworku (a koneckonců i současného, „moderního“ homeworku). Daný omyl vydatně přiživují zejména média, a to nejen česká - jak o tom svědčí např̀. autoři internetových stránek mezinárodní organizace ETO: „Termín telework je často interpretován médii a lidmi obecně ve smyslu homebased telework, ale to je zavádějící (klamná) informace. " ${ }^{61}$

Poněkud názornější představu o tom, jaké místo zaujímá v obecném povědomí nejrozšiřenější pojetí teleworku (tj. home-telework, event. tele-homework) ve spektru obdobných, $v$ současné realitě praktikovaných variant, by mohlo poskytnout následující schéma (viz schéma Rủzné typy realizace práce $z$ hlediska lokalizace hlavního pracoviště na následující straně). Homework a telework (jako součásti obecnějšího outworku) jsou zde znázorněny proti sobě stojícími, zrcadlově obrácenými útvary v podobě písmene „L“-jen jejich „čtverečkovaný“ průsečík, v němž se překrývá horizontální šrafování homeworku s vertikálními liniemi označujícími telework, symbolizuje to, co mají obvykle lidé pod teleworkem zafixováno.

vat jako teleworker, i když jako právní termín telework de facto neexistuje: „Zákoník práce připoušti v zájmu zaměstnavatelủ práci na dálku a úpravy obsahu pracovněprávního vztahu: sjednání pracovního poměru na dobu určitou s výkonem prací na dálku, rozdělení pracovní doby se střidáním zaměstnancủ na jednom pracovišti a doma, dohody o pracích konaných mimo pracovní poměr v počtu pracovních hodin soustředěných do kratšsho uceleného časového období podle potřebné situace u zaměstnavatele s určením jiného místa výkonu práce apod. Zákoník práce a dalši pracovněprávní předpisy (zejména nařízení vlády č. 108/1994 Sb.) umožňují práci na dálku a vytvářejí legislativní podmínky pro plnění podnikatelských záměrů a výrobnich, ekonomických i provozních potřeb zaměstnavatelü “ (JouzA, L.: Je možné nař́dit zaměstnanci, aby pracoval doma?; dostupné na: www.profit.cz/archiv).

59 MATEJKA, J.: Distanční výkon práce a jeho právní úprava; dostupné na www.lupa.cz.

60 DYTRT, Z.: Chcete být „in"? Nechodite do práce; dostupné na www.pauza.cz.

61 www.eto.org.uk. 


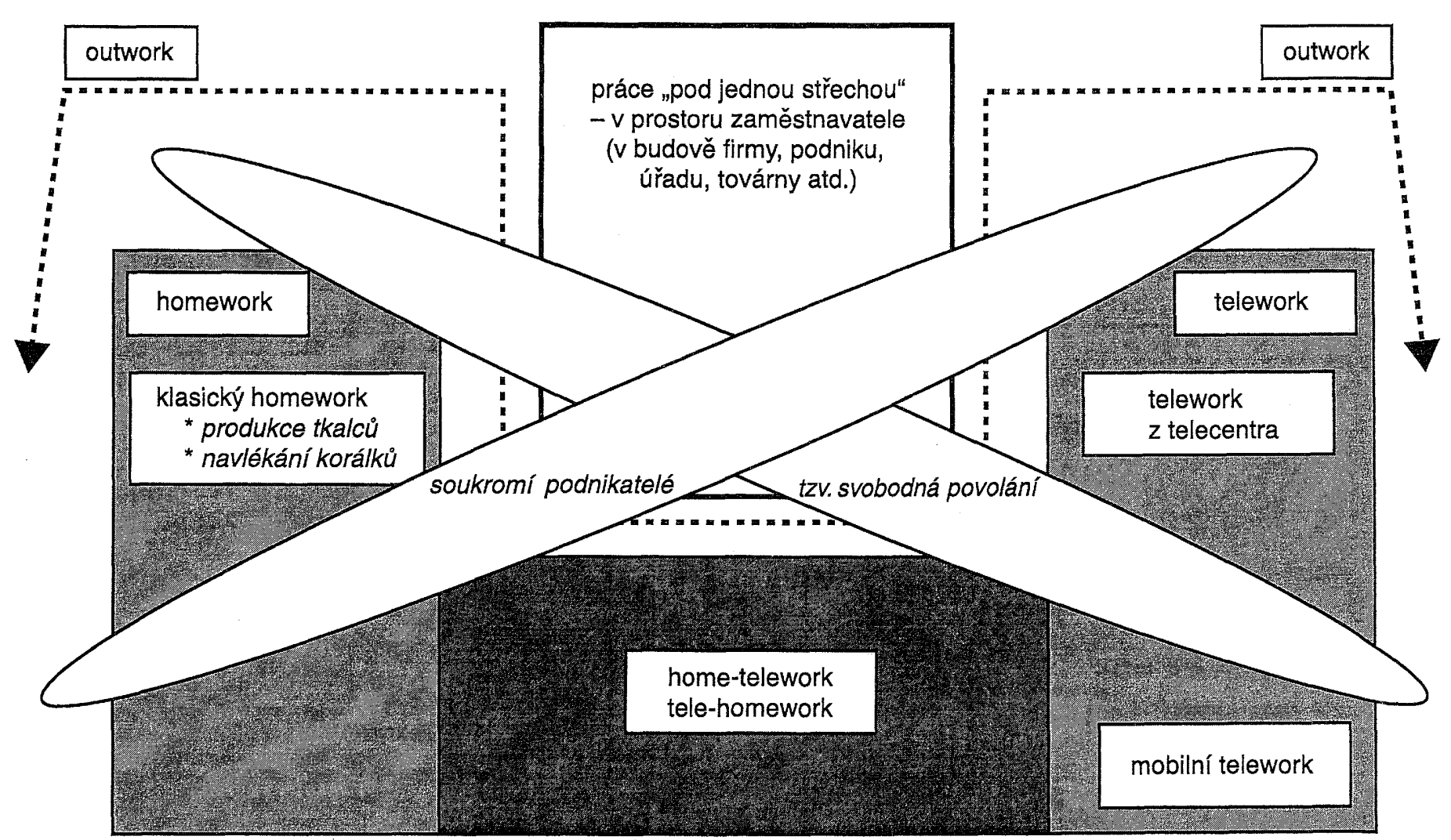

Schéma: Ro̊zné typy realizace práce z hlediska lokalizace hlavního pracoviště 


\section{ZÁVĚR}

Je do určité míry paradoxní, i když nikoli neobvyklé, že ačkoli telework ve všech svých různých konkrétních podobách ve světě zakořenil a úspěšně se rozvijí, ${ }^{62}$ není vlastně př́liš jasné to, $\mathbf{C O}$ zakořenilo a $\mathbf{C O}$ se rozvijí. Definovat telework je stále problematické a stále zůstává úkolem pro budoucnost, byt snad nejbližší. Nedá se říci, že by $v$ tomto ohledu chyběla snaha - o vymezení teleworku se (především pod tlakem nutnosti z hlediska pracovního práva) neustále ${ }^{63}$ pokouší organizace a instituce různého obsahového zaměření, národní i mezinárodní, odborářské i zaměstnavatelské, oficiální (např. ministerské) i neoficiální (hlavně sociální hnutí), politické i vědecké atd. I když v mnoha ohledech se i do budoucna počítá s tím, že nuance ve vymezení teleworku bude nutno ponechat $\mathrm{v}$ národních pravomocích (vzhledem $\mathrm{k}$ národním specifikám pracovní legislativy), s největším očekáváním se asi setkává stále pokračující úsilí o vytvoření nového mezinárodního Kodexu práce.

\section{Literatura}

Accord-cadre sur le télétravail; dostupné na www.teletravailonline.com

AZ Dictionary; dostupné na www.infoplease.com

BARYLAK, M. Telework; dostupné na www.vilspa.esa.es/staff/iue/

BATES, P. - HUWS, U. 2002. Modelling Work in Europe. Estimates, models and forecasts from the EMERGENCE project. IES Report 388; dostupné na www.employment-studies.co.uk

BĚLINA, M., a kol. 1997. Pracovní právo. Praha: Spolek čs. právníků Všehrd.

BLANPAIN, R. The legal and contractual situation of teleworkers in the European Union. The law aspects including self-employed. Consolidated Report; dostupné na www.eurofound.eu.int/publications/

Diskuse k teleworkingu, Hradec Králové, 24. 3. 2003, ISSS 2003; dostupné na www.isss.cz/download/prezentace/kucera__spis.ptt

DRBALOVÁ, V. Zasedal Výbor Evropské komise pro sociální dialog; dostupné na www.spcr.cz/cz/ri/ 11_2003w/esfl.htm

DYTRT, Z. Chcete být , in"? Nechodte do práce; dostupné na www.pauza.cz

HUUHTANEN, P. The Social Dimensions od Telework: The health and safety issues for teleworkers in the European Union. Consolidated Report; dostupné na www.eurofound.eu.int/publications

HÜTTLOVÁ, E. Distanční práce zajímá zaměstnance i zaměstnavatele; dostupné na www.vse.cz HYNEK, J. Čeká nás práce na dálku? Moderní řizení; dostupné na Modernirizeni.ihned.cz/ JOUZA, L. Je možné nař́dit zaměstnanci, aby pracoval doma; dostupné na www.profit.cz/archiv

KROFT, M. - KUČERA, A. 2002. Teleworking. Materiál předkládaný ministru práce a sociálních věci Čr; dostupné na www.spis.cz/spis/SPIS.home

62 Dủkazem mohou být na internetových stránkách pravidelně uveřejňované seznamy institucí, které nějakou formu teleworku již praktikují; viz např:: IBM Austria - alternující a mobilní telework; Zürich Kosmos - mobilní telework; Raiffeisen Rechenzentrum Wien - homework, alternujicí telework; IBM Germany - alternující telework; German Telekom - alternující telework; Lufthansa Systems - alternující telehomework; National Telecommunications Sector Italy - telehomework, mobilní telework, práce z telecentra; Saritel - homework; Italtel - telehomework; Seat - telehomework; Telecom Italia - telehomework; Caridata - soukromá centra teleworku (www.mirti.com).

63 Jednou $\mathrm{Z}$ posledních iniciativ byla nap̌̌. konference o sociálním dialogu v Lublani v lednu 2004, na níž jednotlivé členské federace zemí EU podaly zprávu o implementaci Dobrovolné dohody o teleworku. S uznáním se kvitovalo, že i sociální partneři se zabývají problematikou teleworku, že proběhly první konzultace $\mathrm{v}$ rámci př́slušného týmu RHSD a telework společně $\mathrm{s}$ jinými atypickými formami organizace práce bude zakotven v prúpravovaném kodexu práce. (DRBALOVÁ, V.: Zasedal Výbor Evropské komise pro sociální dialog; dostupné na www.spcr.cz/cz/ri/11_2003w/esfl.htm.) 
La Charte Européenne du Travail à Distance; dostupné na rad2000.free.fr/chareuro.htm MATEJKA, J. Distanční výkon práce a jeho právní úprava; dostupné na www.lupa.cz

PENNINGS, F. The Social Security Position of Teleworkers in the European Union. Consolidated Report. EUROPEAN FOUNDATION for the Improvement of Living and Working Conditions: www.eurofound.eu.int/publications/files/WP9727EN.pdf

PETERKA, J. - VESELYY, V. Tři pilǐre na podporu znalostní ekonomiky. Návrh k veřejné diskusi; dostupné na www.park.cz/article.asp?sec $=3$

RUŠČ́KOVÁ, D. 2001. Teleworking - práce pro ukázněné. Computer World 12; dostupné na www.cw.cz/cwarchiv.nsf/0/

SVOBODA, A. 2000. Je teleworking prací pro dobytek? Computer World 31; dostupné na www.cw.cz/cw.archiv.nsf/0/

TELEWORK Data Report (Population Survey). Ten Countries in Comparison. Bonn 2000; dostupné na ecattlwp1 IGPSWNKITAlgps_data_report2.doc

„Trh práce v pohybu. Práce na dálku“. In: Ekonom 48, 1991.

What are Telework, Teletrade and Telecooperation?; dostupné na www.eto.org.uk/work

Základní formy teleworku; dostupné na athena.zcu.cz/batcos/demo_cz/

www.eto.org.uk

www.eurofound.eu.int

www.mirti.com

www.teletravailonline.com

\section{Homework, Telework and Co. (or Too many "Works")}

\section{Summary}

Over roughly the last 20 years there have been (as there continue to be) a series of changes in the work sphere associated primarily with the mass introduction of new information technologies. One of these new trends is so-called telework (prefigured by homework). All kinds of forms of telework are being practised in many countries, but it is still not quite clear what precisely this category covers, even though attempts to define and characterise homework and telework and individual concrete types of telework are quite frequent, both at the international and state level. This article is concerned with the basic problems of content involved in trying to define homework and telework. 